\title{
5. The Impact of Mining Development on Settlement Patterns, Firewood Availability and Forest Structure in Porgera
}

JERRY K. JACKA

\section{'Wood for Sale': The Firewood Crisis in Porgera}

In the late 1990s in the Porgera Valley, Porgerans frequently described a common difference to me between their country and mine - the United States. For Porgerans, the common refrain was that Papua New Guinea (PNG) was a free country (fri kantri in Tok Pisin). Whereas everything in the United States costs money, everything in PNG was free - firewood, water, food, building materials and so forth. All one had to do was walk into the surrounding rainforest, cut down trees for lumber, harvest lianas for lashing together timbers, build a house, make a fence, and then plant a garden in the cleared space for food. Water for crops and people would be provided by the abundant rains and numerous springs found throughout the landscape.

By 2006, however, things in Porgera were no longer quite so 'free'. Selim diwai, or 'wood for sale', signs lined the Enga Highway along the several-kilometre stretch from the security checkpoint at the Mt Maip boom gate to the outskirts of the world-class Porgera Gold Mine. Most surprisingly, the wood that was 
for sale was not pre-cut lumber for building, but was just plain firewood. Bundles of four 6-foot-long split pieces of firewood were being sold for K4 (about US\$1.20) apiece. Not only was I shocked to see firewood being sold, but in the six years since I had last visited Porgera, I couldn't but help notice the intensive cutting of forest that had occurred along the highway as well. In fact, this is why I had returned to Porgera. One of the things I was interested in trying to understand was how migration into the valley was impacting forest resources. From a population of around 9,000 when the mine was first built in 1990, to an estimated population of over 40,000 today, I was interested in exploring how access to and control over resources, and the resources themselves, were faring in the era of mining development.

At the outset I want to stress that the relationship between forest exploitation and population increases cannot be explained in reference to simplistic associations related to carrying capacity and other kinds of 'balance of nature' arguments (Scoones 1999). Instead, I want to examine the issue of resource extraction and access to resources through a political ecology of development and human-forest dynamics that addresses political economy and ecology equally (Vayda and Walters 1999). As a consequence, I see the firewood crisis in Porgera as mutually constituted by sociocultural and ecological factors. From a sociocultural perspective, I explore Porgeran conceptions of land tenure, but do so from the recognition that different ethno-ecological zones related to relative altitude structure the claims that different actors can make regarding certain resources. From an ecological standpoint, I highlight forest succession dynamics in these different altitude zones and link them to economic and cultural uses by Porgerans to understand some relationships between forest exploitation, ecological succession, and sustainability of harvest in the different altitude zones.

\section{Fuelwood Demands and Deforestation in Rural Global Settings}

About half of all the timber cut globally is used as fuelwood and, of this amount, around 90 per cent is used in developing countries by rural populations for cooking and heating purposes (Parikka 2004). While the cutting of trees for fuelwood is sustainable in some cases, it has been estimated that wood cutting in tropical forests for lumber, charcoal production and fuelwood 'constitute $68 \%$ of the proximate causes of deforestation in Africa, 89\% in Asia, and $51 \%$ in Latin America' (Naughton-Treves et al. 2007: 233). Even in areas where deforestation is not occurring, harvesting can result in changes in species composition and ecosystem function, as fast-growing secondary species replace slow-growing, 
old-growth species. Moreover, as is well documented by a number of ecologists, often species compositions after human disturbance do not return to levels that existed prior to human use (Holling 1973). Nevertheless, management plans in many countries wrongly assume that successional pathways in cleared tropical forests will lead to ecosystems similar to the ones that existed before clearing, that this will happen fairly rapidly, and that species richness will be similar to the original forest (Struhsaker 1997; Chapman and Chapman 2004). There are of course no forest management plans in place in Porgera, as land management is in the hands of customary social groups. However, as the data herein indicate, more holistic management plans and socio-economic impact studies need to take into account long-term ecological changes brought not just by the impact of whatever resource is being extracted, but also by the impacts of migrants, many who will stay in resource development zones for years, if not decades (Dambacher et al. 2007). In PNG, it is estimated that 23 per cent of the rural population lives in areas where firewood is sold, and between 1990 and 1995 firewood sales generated an estimated K5 million income annually for rural villagers (Bourke and Harwood 2009: 392). The expansion of developmentrelated economic activities in the coming years will only increase the tensions surrounding fuelwood availability as land is cleared through logging, plantation development, and mining and petroleum ventures.

The protection of forests in PNG is critical as the island of New Guinea contains the third-largest extant bloc of rainforest in the world (Primack and Corlett 2005). New species are constantly being discovered and little ecological work has been done since the transition to independence in the mid-1970s. In 1972, approximately 29 million hectares of rainforest covered PNG, which constituted about 62 per cent of the country's land cover. By the end of the twentieth century, between 3 and 5 million hectares of this forest had been cut.

Currently in PNG, the varying impacts of the drivers behind deforestation and the rates of deforestation overall are the source of some controversy (Shearman et al. 2008, 2009, 2010; Filer et al. 2009; Filer 2010). As a result of the PNG government's central role in the UN-REDD program ${ }^{1}$ (United Nations Collaborative Programme on Reducing Emissions from Deforestation and Forest Degradation in Developing Countries), Filer and colleagues (Filer et al. 2009; Filer 2010) argue that the PNG government has inflated the past, present and future rates of deforestation in order to obtain the greatest benefits from the REDD program. The source of the controversy stems from three different studies of deforestation in PNG, all of which appear to demonstrate varying rates of deforestation:

1 Technically, the PNG government is involved in REDD+, which goes beyond just deforestation and degradation and includes conservation, sustainable management and enhancement of forests. See Gabriel, Chapter 10, this volume, for more information about REDD+. 
- the Remote Sensing and Land-Use Project (RSLUP) associated with Shearman and colleagues (Shearman et al. 2008, 2009)

- the Forest Inventory Mapping System (FIMS), which Filer and colleagues rely upon (Filer et al. 2009; Filer 2010)

- assessments by the Food and Agriculture Organization of the United Nations (FAO 2005, 2010), which are derived from the FIMS findings (Shearman et al. 2008: 117-8; Filer et al. 2009: 813), although the data between the latter two do not match one another (see Table 5.1)!

Central to each of these studies are slippery definitions of such terms as: 'deforestation', 'degradation', 'primary forest' and 'primary rainforest'. Moreover, the data these studies draw on are scattered throughout various sources (much of it inaccessible grey literature) and the methods for which land-cover classification was determined (in the FIMS and FAO datasets) are not comprehensively detailed.

Deforestation comes from many sources: logging operations, natural and anthropogenic fires, plantation development, subsistence agriculture and mining. In many instances, forest is converted to grasslands, scrub or agricultural land, which may persist for decades (Shearman et al. 2009: 379). Shearman and colleagues $(2008,2009)$ list commercial logging and subsistence agriculture as the two primary drivers in the loss of primary rainforest, and attempt to demonstrate that increasing population results in loss of primary forests. This contradicts what shifting cultivators themselves say - who prefer to use secondary forests - and recent studies looking at agricultural intensification in PNG (Allen et al. 2001; McAlpine and Freyne 2001). I will address this in greater detail later in the chapter as the Porgera data support the intensification argument to some degree.

At issue in the deforestation controversy is how much primary rainforest existed in 1972 (the date at which the Australian government compiled most of the aerial photos of the country, which were subsequently used in making 1:100,000 topographic maps with land-cover features; both FIMS and RSLUP used this data for their 1972 baseline). According to FIMS, there were 29,317,500 hectares (ha) of primary rainforest in PNG in 1972. RSLUP figures state that there were actually 33,227,590 ha. As Filer et al. (2009) exclaim, this is a difference of almost 40,000 $\mathrm{km}^{2}$ ! Given this discrepancy between initial numbers, RSLUP claims that nearly one-quarter (23.8 per cent) of PNG's forests were cut between 1972 and 2002, while FIMS reports a loss of only 10.9 per cent between 1972 and 1996. The source of this discrepancy perhaps lies in a slippage of how terms like 'intact forest', 'primary forest' and 'primary rainforest' are used by the RSLUP team and how 'total gross forest' and 'adjusted gross forest' were used by FIMS (see Filer et al. 2009: 813-4). The RSLUP team writes, 'In 2002 
there were $28,251,967$ ha of rain forest ... with an additional 3,409,018 ha of swamp forest, 574,876 ha of mangroves, and 750,309 ha of dry evergreen forest. Of the rain forest, 25,332,253 ha were primary forest and 2,919,714 ha were secondary forest' (Shearman et al. 2009: 383). In summary, there are multiple classes of forest: primary rainforest, secondary rainforest, dry evergreen forest, swamp forest and mangroves. For 1972, however, the land-cover classes were 'intact forest, mangroves, scrub, grassland, and water. For the change analysis, land-cover classes were combined into two categories: forest (rain forest) and nonforest (non-rain forest)' (ibid.: 381). This raises the critical question of what happened to the 4,159,327 ha of swamp and dry evergreen forest from 2002 were they included in the 1972 'intact forest' category? For the remainder of this chapter I will assume so, and for the purposes of clarifying and comparing the data will assume that these two 2002 land-cover categories were similarly sized in $1972 .^{2}$ This also helps to account for the $40,000 \mathrm{~km}^{2}$ discrepancy between the RSLUP and FIMS data. Table 5.1 summarises these new amounts, removing 4,159,327 ha from RSLUP's 1972 estimate of over 33 million hectares of primary rainforest in 1972 .

Table 5.1 Summary of FIMS, RSLUP and FAO studies ${ }^{\mathrm{a}}$ of deforestation in Papua New Guinea.

\begin{tabular}{|c|c|c|c|c|c|c|}
\hline Study & $\begin{array}{l}\text { Area of } \\
\text { primary } \\
\text { rainforest } \\
\text { (ha) }\end{array}$ & $\begin{array}{c}\text { Area of } \\
\text { deforestation } \\
\text { (ha) }\end{array}$ & $\begin{array}{c}\text { Area of } \\
\text { degradation } \\
\text { (ha) }\end{array}$ & $\begin{array}{c}\text { Annual } \\
\text { rate of } \\
\text { deforestation } \\
(\%)\end{array}$ & $\begin{array}{c}\text { Annual } \\
\text { rate of } \\
\text { degradation } \\
(\%)\end{array}$ & $\begin{array}{c}\text { Total } \\
\text { annual } \\
\text { rate }(\%)\end{array}$ \\
\hline $\begin{array}{l}1972 \\
\text { FIMS }\end{array}$ & $29,317,500$ & \multirow{2}{*}{$3,209,600$} & \multirow{2}{*}{$1,922,300$} & \multirow{2}{*}{0.46} & \multirow{2}{*}{0.27} & \multirow{2}{*}{0.73} \\
\hline $\begin{array}{l}1996 \\
\text { FIMS }\end{array}$ & $26,107,900$ & & & & & \\
\hline $\begin{array}{l}1972 \\
\text { RSLUP }\end{array}$ & $29,068,263$ & \multirow{2}{*}{$3,736,010$} & \multirow{2}{*}{$2,919,714$} & \multirow{2}{*}{0.43} & \multirow{2}{*}{0.33} & \multirow{2}{*}{0.76} \\
\hline $\begin{array}{l}2002 \\
\text { RSLUP }\end{array}$ & $25,332,253$ & & & & & \\
\hline $\begin{array}{l}1990 \\
\text { FAO }\end{array}$ & $31,329,000$ & \multirow{2}{*}{$2,985,000$} & \multirow{2}{*}{$1,886,000$} & \multirow{2}{*}{0.48} & \multirow{2}{*}{0.30} & \multirow{2}{*}{0.78} \\
\hline $\begin{array}{l}2005 \\
\text { FAO }\end{array}$ & $28,344,000$ & & & & & \\
\hline
\end{tabular}

a FIMS = Forest Inventory Mapping System, RSLUP = Remote Sensing and Land-Use Project, FAO = Food and Agriculture Organization of the United Nations.

b This is equivalent to what FIMS called 'adjusted gross forest area' (see Filer et al. 2009). FIMS data are reported in square kilometres; RSLUP and FAO data are in hectares.

Source: Shearman et al. (2008, 2009), Filer et al. (2009), Filer (2010), FAO (2005, 2010).

2 Of course they were not the same area, but it is probably safe to assume that there were no commercial logging operations in these forest types that would have diminished them from their 1972 area. 
As Table 5.1 demonstrates, once the confusion generated by RSLUP's 1972 'intact forest' and 2002 'primary rain forest' is accounted for, the FIMS and RSLUP data are almost identical in terms of primary rainforest in 1972 and subsequent deforestation. Moreover, the total annual rate of deforestation and degradation are very similar across the three studies (see the last column in Table 5.1). Degradation in Table 5.1 refers to the 2.9 million ha of secondary rainforest as documented by the RSLUP group. This was forest that had been logged and was naturally regenerating. According to FIMS, this amount was 1.9 million ha; however, since PNG's logging industry was booming in the late 1990s (Filer et al. 2009, Figure 1; Shearman et al. 2009, Figure 5) this may account for this difference. The FAO figure of $1,886,000$ ha of degraded forest comes from the sum of their categories of 'naturally regenerated forests' and 'planted forests' between 1990 and 2005. In Table 5.1, annual rates of deforestation and degradation have been linearly extrapolated. As argued by Shearman et al. (2009: 388), this ignores the recent increase in deforestation and degradation stemming from the uptake in commercial logging. As such, they modelled deforestation and degradation to each year based on the volume of timber exported, oil palm exports, increases in population and the intensity of El Niño events to account for logging, plantations, subsistence agriculture and fire as primary drivers (ibid.: 383). As such, they came up with annual rates of deforestation varying from 0.4 per cent in 1972-73 to 1.4 per cent in 2001-02, with a peak of 1.8 per cent in 1997-98. In primary forests accessible to commercial loggers, they calculated the rate of deforestation at 2.6 per cent per annum. These numbers are decried by Filer (2010: 151) as exaggerations stemming from the 'moral hazards' that REDD poses to 'rainforest nations' that seek to claim benefits from reducing greenhouse gas emissions from fictitious levels of deforestation and degradation. This is a point well made; however, recent data from the FAO show a rate of deforestation in PNG of 1.51 per cent per annum from the years 2005 to 2010 (FAO 2010). Importantly, as Filer et al. (2009: 813) note, a significant part of what is being classified as forest loss is part of the subsistence cycle of shifting cultivation in which more than 80 per cent of Papua New Guineans are engaged. However, in the absence of detailed ecological studies it is difficult to state with any certainty how an increasing population in PNG with larger demands on the forest will influence future forest regeneration, although the discussion later in this chapter deals with some possible implications based on the data in Porgera.

What I have tried to do in this section is sift through the data on deforestation in PNG and attempt to show that a recent controversy over the rate of deforestation isn't perhaps quite so controversial after all once confusion over terminology and land-cover categories is accounted for. Nevertheless, whether the annual rate of deforestation of primary rainforest is 0.46 per cent, 1.4 per cent or 1.51 per cent, these are still alarming numbers given the vast area of 
rainforest cut each year in PNG. Between 2005 and 2010, the FAO estimates that 427,000 ha of primary rainforest was cut each year in PNG (FAO 2010). This amount of deforestation currently ranks as the second highest in the world. Only Brazil cut more rainforest (more than five times as much as PNG, but Brazil has a forested area 18 times larger than PNG's rainforests).

At this juncture, in discussing forests, I don't want to lose sight of the trees for the forest, for as I discuss in the following sections, it is not the overall clearance of forest that needs to be considered in addressing the firewood crisis in the Porgera Valley, but rather where forest resources are being extracted as a function of altitude, successional dynamics, forest type and resource use rights.

\section{Study Area - Ecological Characteristics}

The Porgera Valley watershed $\left(553 \mathrm{~km}^{2}\right)$ is located in western Enga Province, PNG $\left(5^{\circ} 16^{\prime}-5^{\circ} 33^{\prime} \mathrm{S}, 143^{\circ} 0^{\prime}-143^{\circ} 16^{\prime} \mathrm{E}\right)$. Elevations range from 900 metres in the northern part of the valley and climb to over 3,900 metres in the south. In 2002, based on satellite imagery, approximately 74.5 per cent of the watershed was covered in primary rainforest. Mean annual rainfall is 3,667 millimetres, with very little seasonality. In 30 years of rainfall data, there have been only three months that received less than 100 millimetres of rain. The mean daily minimum temperature is $11.8{ }^{\circ} \mathrm{C}$, and the mean daily maximum temperature is $20.2{ }^{\circ} \mathrm{C}^{3}$ The remainder of the land cover in the watershed is grasslands ( 3.1 per cent), gardens (10.6 per cent), secondary forest (9.1 per cent) and mining/built up areas (2.6 per cent).

Ecologists and local groups alike offer multiple ways of defining the various forest zones in PNG. Robbins (1961) characterises forests from 3,000 to 9,000 feet (914-2,743 metres) as lower montane rainforest; similarly, Paijmans (1976) sets lower montane rainforest as occurring between 1,000 and 3,000 metres, whereas Johns (1982) defines lower montane as occurring at 300-1,000 metres in its lower limits and 1,500-2,000 metres in its upper limits, and mid-montane rainforest occurring at 1,500-2,000 metres in its lower limits and 2,700-3,000 metres as the upper limits. While many ecologists have tried to use features of forest structure (such as canopy height, presence/absence of buttressed trees and so forth) to delineate forest types, often these designations are characterised by linking dominant species to the divisions, such that lower montane is often associated with oaks (Castanopsis acuminatissima) and mid-montane with southern

3 Rainfall and temperature data come from the Porgera Joint Venture mine records. All readings were taken at Anawe at approximately 2,300 metres altitude. Rainfall data is from 1974 to 2004; temperature data is from 1988 to 2004. 
beeches (Nothofagus sp.). Using these nodal forest types, 'Castanopsis' as lower montane and 'Nothofagus' as mid-montane 'has additional value because it fits more closely with altitudinal zones shown by the birds of New Guinea as well as enabling the major zone of population pressure to be more easily defined for planning of conservation measures' (Johns 1982: 309).

Various highlands groups show as much diversity in describing forest types as ecologists. Among the Nimai, there are two divisions, 'the upper part [is] dimina, which they contrast with the lower same on the basis of altitude, temperature, crop types and maturation periods, and general vegetation cover. While no sharp boundary separates these two zones, for reference to them is usually relative, the 2,100 m contour line approximates the division' (Hide et al. 1979: 5). Majnep and Bulmer (1977: 35-6) describe five ecological zones that the Kalam delineate: above 2,300 metres is kamay-agn 'at the base of the smallleaved southern beech trees', at 2,300-2,100 metres is a 'sweet potato' zone, at 2,100-1,850 metres a 'taro' zone, at 1,850-1,600 metres a 'sugarcane, taro, and banana' zone, and below 1,600 metres is the $n m l$ zone where marita (fruit pandanus, Pandanus conoideus) and black palm grow. They note that the zone below 1,600 metres is the one where it is easiest to grow crops. Hyndman (1979) describes a four-part division of environmental zones among the Wopkaimin. As can be seen from this brief survey, groups across the highlands recognise important altitudinal differences in respect to resource management and use.

In Porgera there are three environmental zones that Ipili speakers recognise (Figure 5.1). Below about 1,700 metres is a zone called wapi. Similar to the Kalam, this is a zone recognised for its high productivity, but due to dangerous forest spirits it is not used for gardening and living (Jacka 2010). However, it is an area that is used for hunting and foraging. Between about 1,700 to 2,100 metres is the andakama, literally 'the place of houses and cleared spaces'. This is the zone in which most gardening is done. Above about 2,100 metres is the aiyandaka, literally 'the place of beauty'. It is the high, wet, cold rainforest in which beautification rituals were conducted by young men and women who were preparing themselves for the rigours of life as sexually active, reproductive adults (Biersack 1998, 2004). The altitude boundaries are rather rough estimates as, similar to the Nimai, Porgerans distinguish the zones not on actual altitude, but on a range of factors relating to soil type, temperature, and presence or absence of critical species. Two of the most important markers that delineate the zones are the fruit pandanus, signalling the beginning of the lower zone (as entered from the middle zone), and various cultivars of wild pandanus (Pandanus brosimos) that signal the upper zone. GIS analysis that I conducted of aerial photos and satellite data from 1972 supports using 1,700 metres and 2,100 metres as good points at which to distinguish the zones. In 1972 in the eastern Porgera Valley, 78.1 per cent of the total area for gardening was found 
between 1,700 and 2,100 metres, 14.9 per cent occurred below 1,700 metres, while only 7 per cent of total garden area was found above 2,100 metres. There were no gardens below 1,400 metres or above 2,300 metres in 1972. With the development of mining and the completion of the Enga Highway, this would radically shift by the 2000s, as most occupation occurred above 2,100 metres in the aiyandaka. The implications for this transformation are explored later in the chapter.

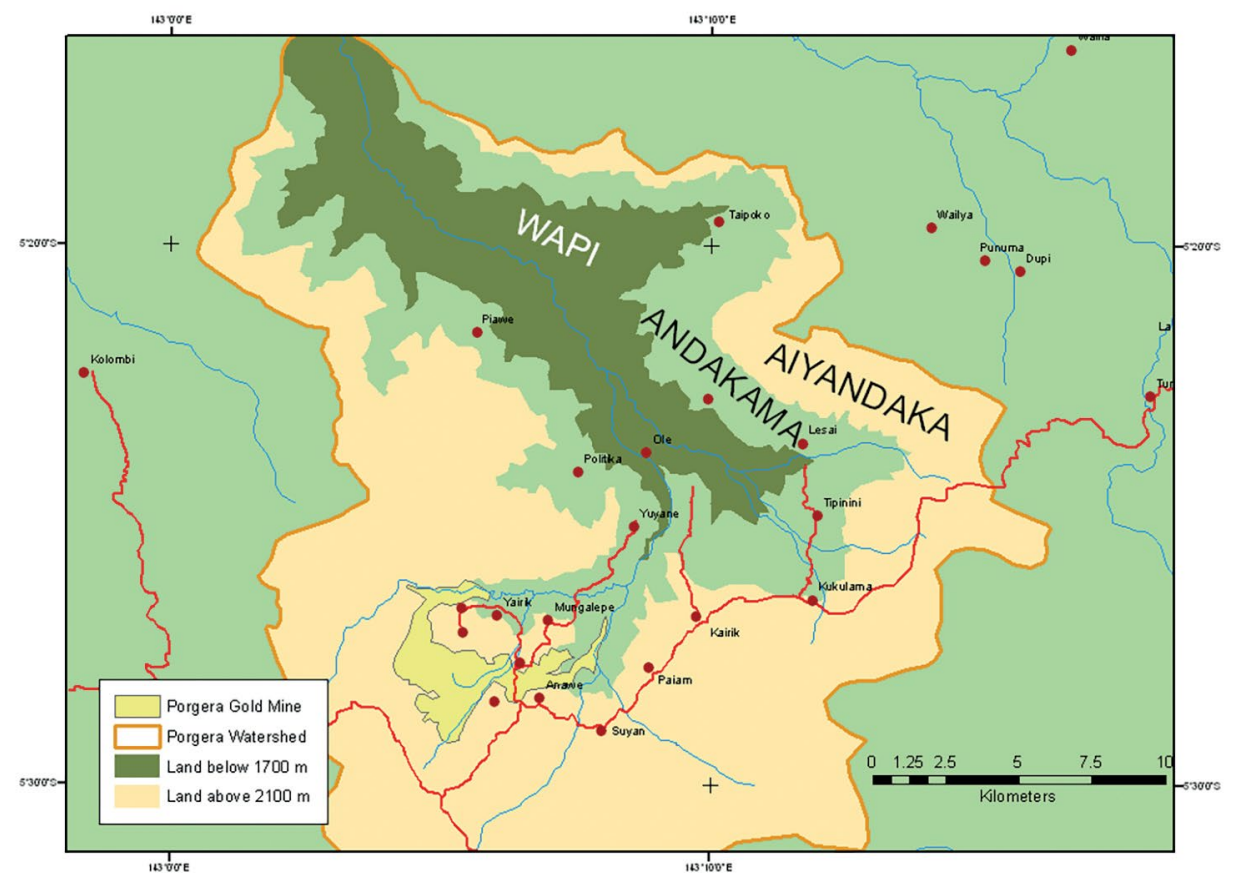

Figure 5.1 Environmental zones recognised by Ipili speakers, Porgera Valley. Source: Image created by author using ArcGIS.

\section{Social Context and Land Tenure Rules}

Porgera is known most famously for its extensive epithermal gold deposits discovered in 1939. Small-scale expatriate mining began in 1948 with local miners becoming active from the late 1950s. The 1960s and 1970s saw a few medium-scale sluicing operations develop alongside continuing local mining, but the planning and development for the large-scale Porgera Gold Mine in the mid to late 1980s fundamentally altered the mining scene in the valley. Since production began in 1990, the Porgera mine has been one of the top gold producers in the world, averaging about 900,000 ounces of gold annually. 
Porgera Joint Venture is the operator of the mine. Initially comprising a number of mining companies (most notably Placer Dome, who ran daily operations) and the state, today the joint venture is 95 per cent owned by Barrick Gold and 5 per cent by Mineral Resources Enga, an entity equally owned by the Enga Provincial Government and the Porgera Landowners Association. The Porgera Landowners are members of the seven landowning clans affiliated with the mining lease property.

Since the late 1980s, when mining development began in earnest, outsiders have poured into the valley in hopes of sharing in the wealth generated by the gold extraction (for an overview of issues surrounding the development of the Porgera mine, see Filer 1999; Jackson and Banks 2002). The outsiders are predominantly from neighbouring cultural groups, especially the Huli and Enga, who have long-term kinship and trading links with the indigenous Ipili. Today, I use the term Porgeran to characterise the inhabitants of the valley as so many Enga and Huli have married in, moved in, and built houses and gardens that the social scene today is one of multiple cultures and languages, such that terms such as Ipili, Huli and Enga at best only describe the primary language that some Porgerans speak. However, what is of interest for my purposes in this chapter is to understand how resource rights are determined by a person's link to a landowning group, as rights are not apportioned equally to everyone, especially newcomers.

The basis for social organisation in the valley rests on three principles: land $(y u)$, group (tata or yame) and bilateral kinship principles. In Porgera every named group controls various named blocks of land in the region that are generally demarcated by creeks or ridgelines. What is of importance though is that Porgerans utilise bilateral kin reckoning to determine membership in a group and to regulate property rights. In doing so, Porgeran social organisation ensures that any one person is a member of several groups, generally the eight groups of one's great-grandparents as well as those of their spouse, making 16 groups in all for a married couple to affiliate themselves with. Practically, this would be impossible but it is expected that people will live 'multi-locally' (Biersack 1995), building gardens and houses on two, three or four of their possible kin groups' lands. Most people actually do this for a number of good reasons. A primary reason that people give is that the steep topography, variable soils, and potential for frosts and droughts create a number of different micro-environments such that when one's crops fail in one area, there is a strong likelihood that there will be crops not harmed in another area (Waddell 1975). Another rationale for living multi-locally is the responses that people can make when conflicts break out, such as moving to another group's lands to avoid the fighting and revenge killings that are endemic in this region (Meggitt 1977; Gordon and Meggitt 1985). 
There are several terms that recognise the differences in how a person is affiliated to a group, since they do not have equal membership rights in all of their groups, despite the use of bilateral kin reckoning. Male agnates are tene. All consanguineous women are called wana. The sons and grandsons of women who are consanguineous kin are called wanaini and aiyane lapone, respectively, and a woman's husband who comes to live on his wife's land is a wanakalini. There is a system of incorporation such that multigenerational interaction with a group is recognised through calling a woman's great-grandson tene, just as an agnate is called. What this means practically is that if a man goes and lives with his mother's kin and stays there, raising a family, making gardens and helping in compensations, his grandsons will have the same status as male agnates. The rationale for this according to Porgerans is that in terms of the relationships between people and land, in Porgera there were always too few people and too much land. Besides incorporating cognatic kin, Porgeran groups were also keen to incorporate outsiders, called epo atene, literally translated as 'those who come and stay'. Ideally epo atene would eventually be incorporated as affines through marriage into the group and then within a few generations converted into tene (cf. Wohlt 1995). The importance of all these different kin designations relates to how land rights are assigned in the group.

Land among Ipili speakers is conceptualised as having a 'skin' (umbuaini) and 'bone' (kulini). The skin of the land is the topsoil, plants, trees, structures and gardens, while the bone is all of that underneath the skin. Land is controlled through a communal property system and the bone of the land is said to be 'held' (mina) by the group. Individuals within the group 'own' the land's skin (they are called anduane, 'landowners') and also inherit land from their fathers and mothers and in turn pass their land to their children. Despite the fact that the Ipili term anduane is translated into English as landowner, the true owners are the collective group; individuals merely have long-term and inheritable use rights. Besides inheriting land, one can also gain rights to a piece of land by cutting primary rainforest and then planting a garden or building a house on the land. Even in very old secondary forest, people are aware of who first cut the land (the anduane) and anyone intending to make a garden on old secondary forest that is not their own must find the offspring of the actual owner to receive permission to rework the land. This is rather common as land is frequently loaned out to various people for varying lengths of time, which is one way that hosts, the anduane, recruit people to come and join the group, hoping that in time they will marry in and their children will become tenes. Short-term loans such as these are called yu no atene rights, which translates as something like 'land eat stays' or someone who receives land to stay on and plant a garden. All of these forms of affiliation to a clan are important because they determine the kinds of rights that a person has in respect to gaining access to land, converting 
forest into gardens, and adjudicating conflicts over land. The important thing to note is that these rights are not codified, but are flexible, open to dispute and interpretation, and contingent and context dependent.

Generally, though, tenes make most of the decisions as to how land is allocated and make judgements on disputed lands. In terms of a person wanting to cut primary rainforest to build a house or make a garden, they must gain permission from a tene. With the exception of epo atene and yu no atene, any person in any of these categories can do what they like with inherited lands - they can cut trees, plant trees, or even give away portions of land to others. Epo atene can give land to outsiders to use; these outsiders (themselves epo atene) can't plant trees, although they can cut down trees that are not economically important. All economically important trees in the areas around houses and gardens are individually owned and can only be cut with their owner's permission. Concepts of tree tenure and land tenure are linked in that Porgerans recognise that a lot of effort goes towards maintaining casuarina (Casuarina oligodon) and pandanus (Pandanus julianettii) trees, and hence anyone who has planted them and maintained them should gain access to the land as well. Therefore, people who loan land must remain vigilant to ensure that trees are not being planted on it, or else risk losing that land. Planting trees is a signal that one intends to claim the land permanently for one's self and one's kin.

Thomas Igila, a Huli man, related a story to me that may well be hearsay, but the message indicates how powerful the concept of planting trees is in terms of land ownership. He told of how a group of Huli in Port Moresby was given a patch of land to garden on by some local landowners. After a while, the Huli asked if they could plant trees on the land and the local landowners allowed them to do so. At that time, the Huli then logically assumed that they were being given the land since they were told they could plant trees on it. When the local landowners asked for the land back after a few years, the Huli refused to relinquish it. According to Thomas, the case went all the way to the Supreme Court of PNG, which found in favour of the Huli. As mentioned, I don't know if a case like this ever made it to the Supreme Court, but as far as local land court cases go in Porgera, people surreptitiously planting trees on land to take it over was a constant source of litigation. In nearly every case, the land is given to the person who has planted trees on it.

In summary, traditionally Porgeran social groups were faced with two facts: abundant land and insufficient numbers of people to defend the group against aggressors. Coupled with unpredictable environmental conditions that challenge their high-altitude subsistence system, and endemic conflict, Porgeran culture responded by having a very flexible social organisation that had numerous mechanisms for incorporating cognatic kin and even outsiders by offering agnatic-like kinship status and land. In the context of mining, though, land 
has become less abundant. It is still considered important to have a large group, as conflicts are still endemic. One result is that people welcome outsiders, but are less likely to allow them to become true landowners in the sense that they can plant trees and take over lands for their own. Without the right to plant trees, outsiders must then turn to cutting trees in areas of primary forest and secondary forest in order to obtain firewood - enter the firewood crisis of the mid-2000s.

\section{Trees and Land Types}

The land types that I use in this chapter - primary forest, secondary forest, gardens and grasslands - are derived from Porgeran terms. Trees are called ita, and what I am calling primary forests, Porgerans refer to as itapu or ima. Gardens are called $e$, and several kinds of gardens are differentiated. $E$ wene are 'new' gardens where cultivation has not occurred yet, but trees have been cut down to make the garden; e siaka, or an 'alive' garden, is a garden in which sweet potato mounds are being made; $e$ talu, or a 'fertile' garden has crops growing in it; $e$ $s i$ is an old garden with grass growing in it; e pale is an old garden with trees growing in it; and $e$ imati are forests which show traces of ancient or very old gardening. E pale and e imati are what I translate as secondary forests. E pale are secondary forests that are about five to 25 years old. People generally cannot tell how long ago a garden was in an e imati secondary forest, only that it is not ima, primary forest that has never had a garden cut in it. Generally people prefer to make new gardens in e pale, as soil fertility is greater, but trees aren't as large as they are in e imati and ima. Grasslands, which I don't discuss here, are another indigenous land type called puka.

Within the field of environmental studies there is some debate over how pristine primary rainforests really are (Posey 1985; Parker 1993; Fairhead and Leach 1996; Willis et al. 2004). Balée (1989), for example, argues that approximately 12 per cent of Amazonian terre firme forests are anthropogenic. My concern in this chapter is not to argue that primary forests in Porgera have never had gardens in them. The critical point is that Porgerans do not recognise any gardening activity in them that would create large canopy gaps and significantly alter the composition of tree species in ima forests. Ima forests do serve as supply sources for single logs, for which I have seen plenty of evidence over the years. Therefore, the category 'primary forest' for the purposes of this chapter indicates forests that have received only minor disturbance from humans over several decades. 
Culturally, trees figure critically in Porgeran experience. In one origin story, a tawe akali ('sky man' spirit) finds a group of women living and gardening in the eastern Porgera Valley. They all are living in a giant water gourd that he picks up and takes to the sky world while the women are sleeping. While they sleep, he lays out food for them and sharpens an opolanga (Schefflera actinophylla) digging stick for each woman. He wakes the women by playing a bamboo mouth harp (lino) and then feeds them and gives them their digging sticks. After eating, he instructs the women to gently dig up a taiya (Araucaria cunninghamii) tree and plant it next to his house. When they do so, the branches of the tree sprout men whom the tawe akali matches up with the women. These couples then become the ancestors of all the clans in the Porgera area, according to the elder woman who told the story. After hearing this story, my research assistant added, 'They became the ancestors of everyone in the world'. In other origin stories, quasi-mythological ancestors plant a number of important tree species as they move about the landscape. Today, these locales still contain dominant numbers of these species marking the passage of these mythical heroes.

Men have lifelong connections to trees. Porgeran etiquette requires that a husband not ask his wife directly the sex of their newborn child, so he discreetly enquires, 'U pe, nu pe?' which means 'Axe or net bag?' This indicates the cultural implements that define gendered livelihoods in Porgera - axes for men to cut firewood and build houses and fences, net bags (bilums) for women to carry produce and babies. Traditionally, after boys were born, the fathers would take the placentas which had been placed in bilums and tie them to the tops of very high trees so that as the young men grew up they would not be afraid of heights or of climbing trees to de-limb them. Many men whom I came to know personally or through stories - Mata, Bope, Pawa, Tapaiya, Yakati and others - were, I eventually learned, named after tree species. In time, it often became hard to disassociate the man from the shape or quality of the tree. Pawa (Dacrydium sp.), a tree known for its strong wood and prickly needles, became entangled with the Pawa who would beat his wife mercilessly for the slightest of infractions. Yakati, the father of one of my elder key informants, Muyu, I never met, but I could never purge my mental image of him as short and broad like the yakati 'highland breadfruit' (Ficus dammaropsis) tree. Many of the names of places and waterways also come from trees. Porgera comes from the poketa tree (Alphitonia incana), which presumably grew along the banks of the Porgera River in sufficient numbers to give that river its name. Likewise for the Tupa and Pongema rivers that share names with their associated tree species. There are at least two place names in the eastern Porgera Valley that come from a tree species - both are called Tatonga, meaning 'at the base of the tato' tree (Nothofagus sp.), a dominant tree in mid-montane forests, as mentioned earlier. 
Trees also figure in important rituals both as metaphor and substance. Magic formulas (kamo) invoke tree species names to mimic qualities found in those species, such as strength, stickiness, smoothness, watery sap and so forth. To ensure that her husband's skin remained healthy and supple, wives would chew the leaves of lioko trees (Acronychia sp.) while staring into the sun and reciting a magical spell. Women also buried used moss menstrual pads at the base of Nothofagus trees, the largest trees in the Porgeran landscape, which as one male informant indicated were 'the only trees strong enough not to be killed by menstrual blood'. Several rituals designated for healing people and renewing the fertility of the earth required the use of specific tree species to build ritual houses and other structures for their properties of strength and fragrance. Other species are used merely for their decorative purposes; for example, many people employ leaf bundles from species that have green shiny leaves with whitish undersides for the contrastive elements that arise when the leaves are in motion.

Economically, trees of course provide firewood, building materials and fencing. In fact, ita means not only tree, but also 'wood' and 'fire'. Perhaps rather than seeing the forest for the trees, trees are seen as 'buildables' and 'burnables'. While some trees are not used for either building or burning, they are used for medicines, rituals and clothing, and as sites for hunting marsupials or birds because of seeds, nuts and fruits preferred by these game animals. Pandanus species are also important for food sources and building materials, and the leaves of one cultivar of $P$. julianettii (tapuna) are used as compost in sweet potato mounds. In 2006, while gathering data on uses of trees, of 110 species $^{4}$ encountered in the field, only one species did not have an economic or cultural use. By far, the most economically important tree is the casuarina (C. oligodon), called yar in Tok Pisin. Casuarinas are planted around houses and in gardens and grow naturally in disturbed areas, such as near landslips and along eroded stream banks (Robbins and Pullen 1965). Besides being the most important firewood species (Bourke and Harwood 2009: 392) due to its long burn time, high heat output and low ash production, casuarina is also a nitrogen fixer, which contributes to its importance in garden locations. Additionally, it is often used for fencing and house building.

At this juncture, I want to look at data I gathered in 2006 on tree successional dynamics in the different environmental zones in Porgera. While anthropogenically planted casuarina is perhaps the most important tree species, naturally occurring trees in secondary and primary forests are also very important and serve as a critical fallback resource when people need more wood than can be supplied by casuarinas, which is fairly often. To understand 
what kinds of trees grow where and in what abundances, comparative analyses were done on the composition of tree species found in the three environmental zones and in the differences between primary and secondary forests. As will be seen, altitude has a significant impact on which trees come up in secondary forests, thereby hampering the abilities of Porgerans to obtain adequate wood for building and cooking in the higher-altitude zone.

\section{Methods}

\section{Forest Transects}

The survey of tree species by land use type and elevation zone was conducted in the eastern part of the Porgera Valley around the Kairik airstrip $\left(5^{\circ} 26^{\prime} \mathrm{S}\right.$, $\left.143^{\circ} 10^{\prime} \mathrm{E}\right)$. This was land held by the Bipe clan, among whom I was living in 2006. This site was chosen due to its proximity to the Enga Highway, and because there were several 'camps' of Engans living nearby who were using trees for house building and firewood, allowing me to explore population pressure on local resources and on tree tenure and land tenure dynamics between immigrant and host communities and individuals. Twenty-two $50 \times 10$ metre $(1.10$ ha in total) transects were sampled. Transects were established in both primary and secondary forest at each of the three elevation zones, with the exception of primary forest in the upper elevation zone, as there is no longer any primary forest in this area (around the Kairik airstrip). What species should have been in primary forest in the upper elevation zone were reconstructed from oral history and data from other sites in the PNG highlands at a similar altitude.

In the lower elevation zone, three areas (1,500 square metres) were sampled in primary forest (at elevations 1,635-1,652 metres) and four areas (2,000 square metres) in secondary forest (at elevations 1,662-1,684 metres). In the mid-elevation zone, five areas (each 2,500 square metres) were sampled in both primary forest (elevations 2,020-2,091 metres) and secondary forest (elevations 2,070-2,092 metres). In the upper elevation zone, five areas $(2,500$ square metres) were sampled in the secondary forest only (at elevations 2,357-2,388 metres). The secondary forest sites ranged in age from eight to 12 years since gardens had last been planted in them. Approximate ages of the secondary forest sites were cross-checked with different informants. Initial locations of all 22 plots were chosen by stratified sampling and direction of plot transect was randomly generated, with the exception of ensuring that cliffs and waterways were avoided. All trees with a diameter at breast height $(\mathrm{DBH}) \geq 10$ centimetres were recorded (Ipili name taken) and measured (DBH). 


\section{Focus Groups}

Two focus groups were organised to gather data on the cultural and economic uses of all trees recorded from the transect data. One focus group comprising older men met on five occasions, while one focus group of younger men met on three occasions. There was general consensus between the two focus groups on the usefulness of certain species as firewood, building materials and harbouring key animals for hunting, but the elder focus group knew substantially more about the ritual uses of certain trees. The focus groups also discussed what kinds of trees would normally be found in the primary forest of the upper elevation zone. A third focus group composed of both younger and older men was used to list freely the most important trees for firewood, house building and fence construction. Once lists were compiled, individual participants were asked to rank the species in each list in order of importance for the three purposes. Again, ranking exercises showed general consensus within the group of informants as to how valuable each listed species was relative to the others.

\section{Tree Identification and Prior Research}

Due to time and budget constraints, voucher specimens were not collected for determination of botanical species in 2006. Species names have been determined by previous work from other researchers and comparison of cognate terms among neighbouring groups. In the 1970s, a dictionary of the Ipili language was compiled by Dr Francis Ingemann and vernacular tree names were recorded and identified in the field by John Womersley, assistant director of the Division of Botany, Department of Forests, PNG (Ingemann n.d.). As well, Ipili and Enga share cognates for several tree species with neighbouring ethnolinguistic groups (Huli and Wola), among whom much species identification work has already been done (Ballard 1995; Sillitoe 1996, respectively). From the entire sample, for all species with five or more individuals, there are only seven species whose scientific names were not determined.

In total, I have conducted 16 months' worth of ethnographic research in the Porgera Valley. Numerous semi-structured interviews on the use of forest resources were held with men and women during a 14-month research period from December 1998 to February 2000, which supplement the findings from the focus groups held in 2006. Forays in the forest with men and women were also a significant focus of research in the earlier research period. 


\section{Results from the Ecological Surveys}

There is a wide variety in the composition of forests in the highlands; although, as mentioned, ecologists have identified highland forests by 'nodal' species that predominate in certain forests - oaks (Castanopsis acuminatissima and Lithocarpus sp.) in the lower montane forests and beeches (Nothofagus sp.) in the mid-montane forests (Johns 1982; also Paijmans 1976). Porgera fits this characterisation well; oaks comprise 40 per cent of all species in the lower elevation zone, and oaks and beeches account for 40 per cent of all species (11 per cent beeches, 29 per cent oaks) in the mid-elevation zone, which corresponds to the boundary between lower montane and mid-montane rainforest of the ecologists. Across all of the sampled sites, 934 individual trees representing 110 species were recorded. Sixty species ( 54 per cent of the total) were represented by four or fewer individuals. Twenty-two species (20 per cent of the total) were represented by only one individual. In summary, Porgera's forests have high species diversity but are dominated by a few species. For instance, at the family level, Fagaceae (oaks) is the most prominent family, comprising 29 per cent of all trees. This is followed by Pandanaceae (pandanus) at 11 per cent, Euphorbiaceae (spurges) at 7 per cent and Cyatheaceae (tree ferns) at 6 per cent of all trees.

As would be expected, however, the abundance and distribution of trees in Porgera varies by elevation and forest type (primary versus secondary). Species abundance can be measured in two ways - by the number of individuals of a species per unit of land or by the amount of wood available for use by a species per unit of land. In terms of the amount of wood available for use, foresters use a measure called basal area, which is expressed in square metres per hectare. A final measure that ecologists use to compare the composition of different species in different sized forest plots is importance value (Krebs 1989). Importance value is a relative ranking of species based upon three criteria: (1) species frequency (how many plots a species occurs in divided by total number of plots), (2) species density (number of individuals per hectare) and (3) species dominance (basal area). Values based on these three criteria are relativised (absolute values are expressed as a percentage of the sum of the absolute values) and are ranked on a scale of 0 to $300 .^{5}$ As my concern in this chapter is to understand which species of trees are economically important, I focus on importance values to highlight which species in each zone and forest type are frequent, dense and dominant.

5 Importance value $=$ relative frequency + relative density + relative dominance. Relative frequency $=$ frequency of one species/total frequency of all species $\times 100$. Relative density $=$ density of one species/total density of all species $\times 100$. Relative dominance $=$ basal area of one species/total basal area of all species $\times 100$. 
In the lowest elevation zone, oaks (Castanopsis and Lithocarpus) are indeed the most important species in both primary and secondary forest. In the midelevation zone, Castanopsis oaks are the most important species followed by Nothofagus beeches. In the upper elevation zone, Nothofagus beeches are the dominant species in primary forests based on informants' information, other studies in highlands PNG (Paijmans 1976; Ash 1982; van Valkenburg and Ketner 1994), and from my own work in upper elevation forests in Porgera outside the area sampled in 2006. Of extreme interest is that in upper elevation secondary forests, no individuals of Nothofagus $\geq 10$ centimetres DBH were found in any of the plots. The most important species were tree ferns (Cyathea sp.), followed by a softwooded pioneer species (Homalanthus nervosus) and the tapuna variety of nut pandanus trees. Table 5.2 summarises the data on importance values in the sampled transects by elevation zone and forest type.

Table 5.2 Trees in each elevation zone and forest type with an importance value $>20$.

\begin{tabular}{|l|l|l|c|}
\hline $\begin{array}{l}\text { Elevation zone } \\
\text { and forest type }\end{array}$ & Species & Ipili name & Importance value \\
\hline \multirow{4}{*}{ Upper secondary } & Cyathea sp. & tambu & 30.4 \\
\cline { 2 - 4 } & Homalanthus nervosus & ambopaiya & 27.4 \\
\cline { 2 - 4 } & Pandanus julianettii & tapuna & 25.0 \\
\hline \multirow{4}{*}{ Middle primary } & Castanopsis acuminatissima & pai & 100.3 \\
\cline { 2 - 4 } & Nothofagus sp. & tato & 50.1 \\
\cline { 2 - 4 } & Syzygium sp. & pipi & 26.3 \\
\hline \multirow{3}{*}{ Lower primary } & Castanopsis acuminatissima & pai & 52.4 \\
\cline { 2 - 4 } & Nothofagus sp. & tato & 25.7 \\
\cline { 2 - 4 } & Castanopsis acuminatissima & pai & 68.4 \\
\cline { 2 - 4 } & Araucaria cunninghamii & taiya & 32.9 \\
\cline { 2 - 4 } & Lithocarpus sp. & yomboto & 22.2 \\
\hline \multirow{2}{*}{ Lower secondary } & Castanopsis acuminatissima & pai & 64.1 \\
\cline { 2 - 4 } & Lithocarpus sp. & yomboto & 38.9 \\
\hline
\end{tabular}

While the data in Table 5.2 show the most important species in each type of forest and elevation, not all trees are as economically important as others, especially in terms of hardwoods used for firewood, fencing and building materials. Another consideration besides what species are present in each zone and forest type is that the actual amount of wood per forest and elevation is highly variable as well. These results are summarised in Table 5.3. 
Table 5.3 Basal area $\left(\mathrm{m}^{2} / \mathrm{ha}\right)$ per forest type and elevation zone.

\begin{tabular}{|l|c|c|c|}
\hline Elevation zone and forest type & $\begin{array}{c}\text { Total basal } \\
\text { area }\end{array}$ & $\begin{array}{c}\text { Basal area of } \\
\text { hardwood species }\end{array}$ & $\begin{array}{c}\text { Hardwoods as } \\
\text { \% of total }\end{array}$ \\
\hline Upper secondary & 17.4 & 9.6 & 55.2 \\
\hline Middle primary & 78.9 & 78.6 & 99.7 \\
\hline Middle secondary & 26.3 & 22.1 & 84.2 \\
\hline Lower primary & 54.8 & 54.6 & 99.6 \\
\hline Lower secondary & 37.3 & 36.3 & 97.3 \\
\hline
\end{tabular}

As seen in Table 5.3, basal area is highest in the primary forests in the midelevation zone. This is a function of the size of Nothofagus trees found in this zone, many of which had diameters (DBH) of over 100 centimetres. The difference between basal areas in the secondary forest in this zone highlights the absence of exceptionally large trees. In the lowest elevation zone, there are no southern beeches. Castanopsis oaks predominate and are much smaller in diameter in general than southern beeches, hence secondary forest does not exhibit such a dramatic difference in change in stand basal area as the mid-elevation zone. The highest elevation zone shows the lowest amounts of useful wood per hectare. No hardwood species were listed as being economically important in terms of firewood, house building or fence construction in the high-elevation zone. However, this zone does provide a greater abundance of resources such as pandanus nuts, pandanus leaves that are used for roofing materials, and tree fern fronds, which are cooked in earth ovens and eaten. Basal area of hardwood species would be higher in highelevation primary forests than secondary forests (if there had been any left in the study area). In 1999, I observed the clearance of high-elevation primary forest throughout the eastern Porgera Valley. Many of the trees cut were huge, buttressed Nothofagus trees. Figure 5.2 shows a wokabout sawmill in operation in 1999 in high-elevation primary forest just to the east of the 2006 study site; the stumps and planks are from Nothofagus trees. 


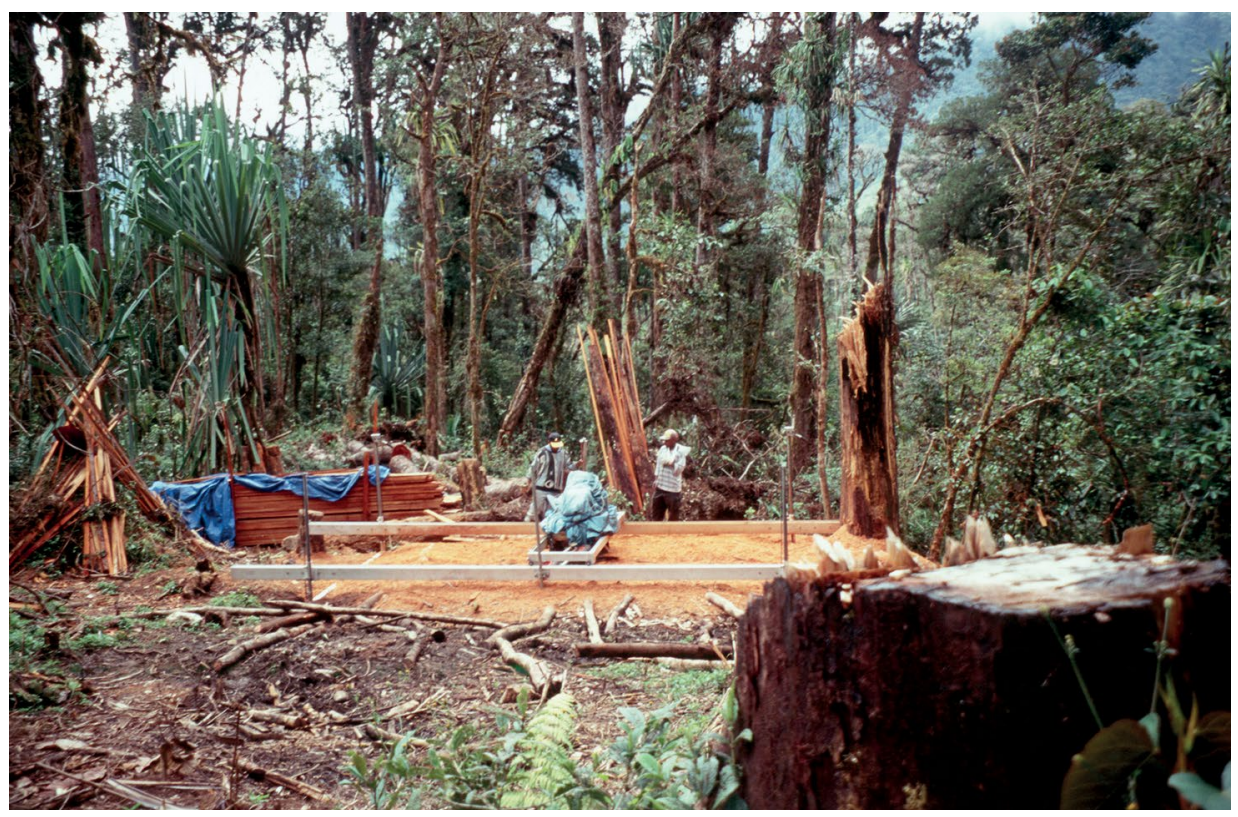

Figure 5.2 A wokabout sawmill in operation in 1999 in high-elevation primary forest, Porgera Valley.

Source: Photo by Jerry Jacka.

\section{Results from the Ethnographic Research}

Based on previous research and participant observation, I was aware of how important casuarina was for firewood and fences. For example, in June 1999, I travelled with my research assistant Peter Muyu to the western Enga hamlet of Punuma. Due to various land disturbances that are common to the local area, Punuma sits in a large grove of casuarina trees. Peter and I were to stay with a distant relative of his named Saima. Saima had just built a new house for himself and his new wife and when Peter and I entered the house, Peter made sounds of whistling approval. I assumed it was over the house construction, but Peter elbowed me and pointed to the rafters above the bedrooms that were stocked full of some 50 or more split, dried casuarina logs. Saima just grinned sheepishly at the good fortune he had of living among such extensive casuarina groves.

As mentioned in the Methods section, in 2006 I was interested in trying to get at some sort of consensus over which trees besides casuarina were of obvious economic importance. The categories that my research assistants suggested we should use were firewood, house construction and fence building. Table 5.4 is a composite ranking of the economically important species, as listed by participants. 


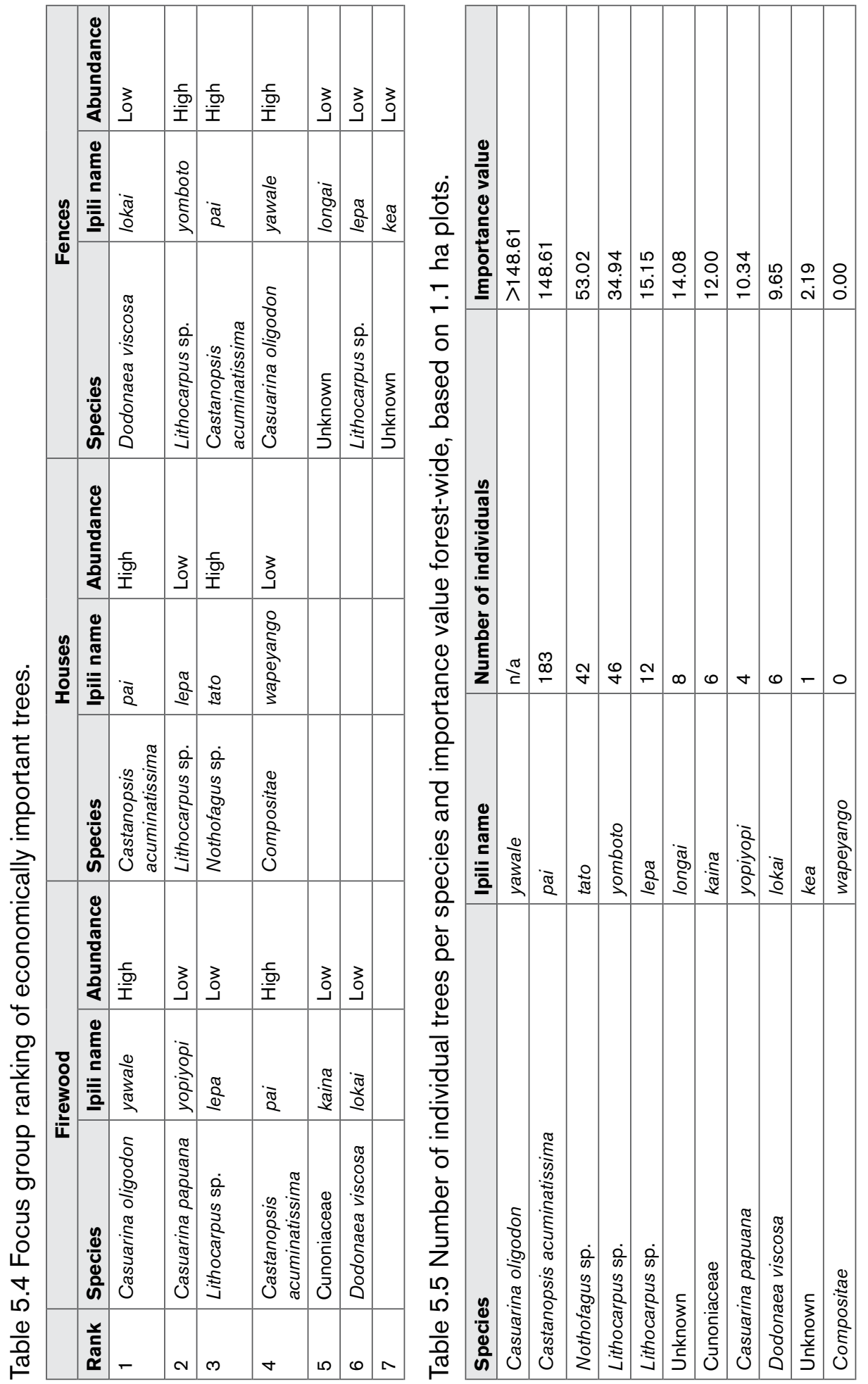


Of all the species that were ranked as being important, only two appear in all three categories - pai (Castanopsis acuminatissima) and lepa (Lithocarpus sp.), both oaks in the Fagaceae family. Moreover, only 11 tree species in total were used to rank economic importance in all three categories. Whereas Castanopsis is the most abundant tree other than $C$. oligodon, the lepa oaks are rather uncommon. For the purposes of abundance, I used the encounter rate across the 1.1 ha plots where 40 or more individuals per species was 'high', 20 to 39 was 'medium', and fewer than 20 was 'low'. Many of the trees that appear in these rankings are low in abundance; it is unknown if this is a factor of being selectively harvested due to their economic importance, or if they are uncommon ecologically. The 11 species from Table 5.4 are ranked using importance values and presented in Table 5.5.

The data in Table 5.5 support the abundance rankings from Table 5.4. The top four species, yawale, pai, tato and yomboto, are the only ecologically abundant tree species that are also economically important. Yawale (C. oligodon) was not used in the calculation of importance values as the numbers of these trees from the 1.1 ha plots do not accurately reflect their actual numbers in the region since people plant them in gardens and around their houses.

\section{Implications}

The combined results of the ecological and ethnographic data point to only three species of tree (pai, tato and yomboto), in addition to one species of anthropogenically planted tree, casuarina (yawale), as occurring in sufficient enough abundance (in terms of both numbers and basal area) for human exploitation for use as firewood, fencing, or building materials. Only one of these three species, tato (Nothofagus sp.), occurs in high-elevation forests. However, this species was not found in any of the plots in upper elevation secondary forests, which indicates that overharvesting of parent species or some other factor is limiting its ability to colonise secondary forest settings at high elevations. Mid-elevation forests contain both pai (Castanopsis acuminatissima) and tato (Nothofagus sp.) in large numbers. Based on importance values (Table 5.2), primary forests are twice as important as secondary forests for these two species at mid-elevations. Yomboto (Lithocarpus sp.) is a very marginal tree in mid-elevation forests (importance value of 1.67 on a scale of 0-300). Nothofagus is not found in low-elevation forests. Table 5.2 shows that contrary to mid-elevation forests, pai and yomboto are of more importance in secondary forests at low elevations. For yomboto, the difference of importance for secondary versus primary forest is marginal. For pai, however, both importance value and basal area are around three times as great for low-elevation secondary forests as compared to primary forests. At this elevation, pai seems to flourish with some 
human disturbance. This is similar to other research on human disturbances of Castanopsis acuminatissima around Wau in Morobe Province (van Valkenburg and Ketner 1994). Van Valkenburg and Ketner also looked at the response of Nothofagus to disturbance (anthropogenic, landslides, fire, storms, etc.) and concluded that both Castanopsis and Nothofagus need disturbance to regenerate, but also need mature species to produce seeds. 'At various places ... the forest is no longer able to recover to maturity and if intensity and frequency of human activities increase, species such as Nothofagus pullei and Castanopsis will also disappear because of lack of seed' (van Valkenburg and Ketner 1994: 53).

These results have great significance given the settlement patterns associated with mining development at Porgera. In the early 1970s, colonial administrators debated the merits of different routes for a road into the Porgera Valley. The main footpath used by colonial patrol officers bisected the most populous portions of the valley for ease of administration and control. A shorter route was eventually chosen that bypassed the main areas of settlement and was located entirely within the high-elevation rainforest at the southern end of the valley (Figure 5.3).

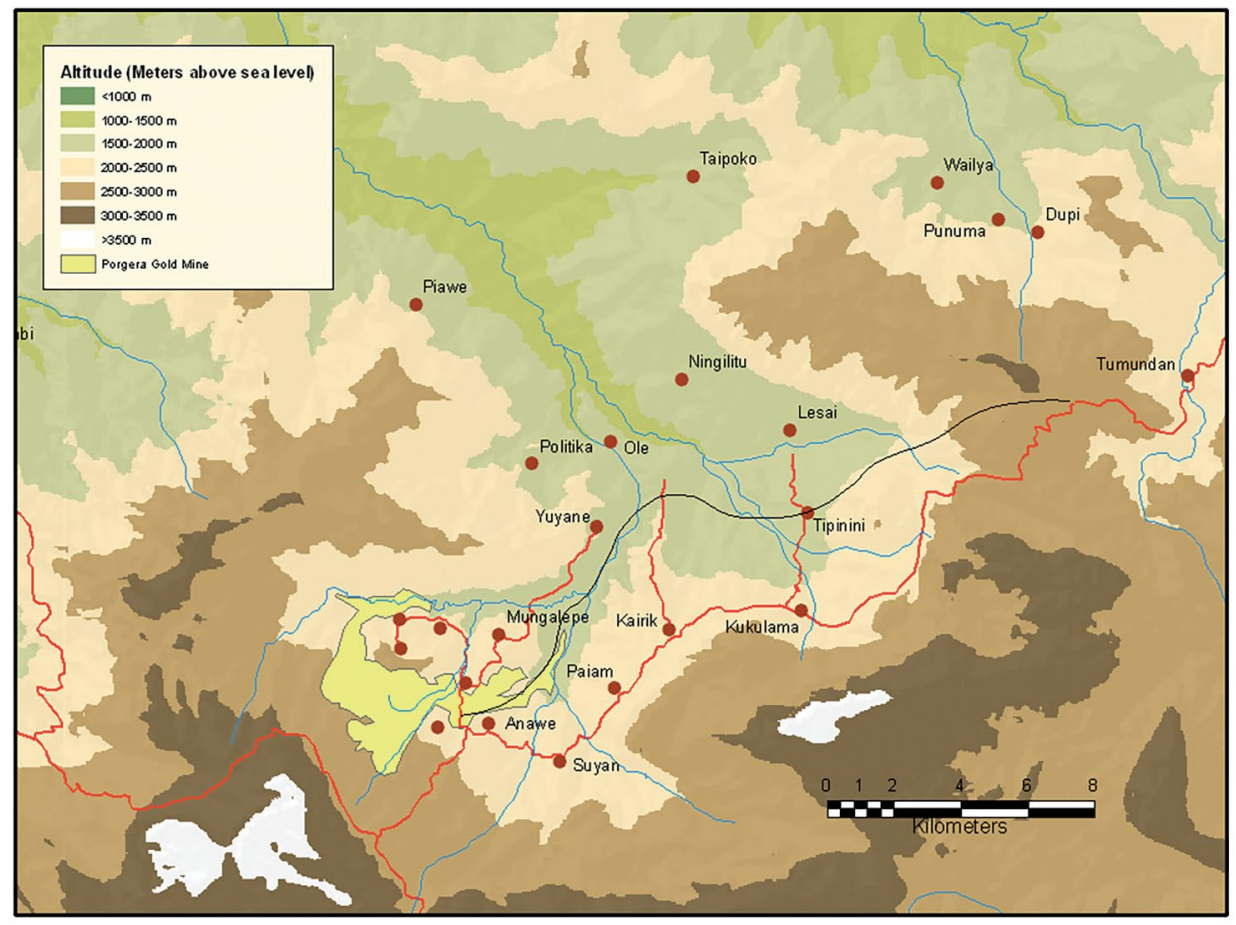

Figure 5.3 The Enga Highway in the Porgera Valley.

Note: The transition in the legend from green to brown delineates 2,000 metres above sea level. Source: Image created by author using ArcGIS. 
Initially, only a few individuals built houses along the road, but with the advent of mining development in the late 1980s, more and more families started to clear forest, build houses and plant gardens adjacent to the road. Around Kairik, big men urged their clansmen to occupy as much land as possible as rumours were circulating that an airstrip to serve the mine would be built next to the road at Kairik. Outsiders were initially welcomed into the area as there was far too much land for the relatively small population. Over the past 20 years, however, population has exploded in the Porgera Valley. From an overall population of 5,011 in 1980, the population increased to 9,255 in 1990 and 22,809 in 2000. Estimated population for 2010 is over 40,000 people. More critically, the population increases have been very uneven, with most of the increases in communities along the road in high-elevation forest. Figure 5.4 shows the rate of population increase in the valley from 1980 to 2000 in the different census units in the Porgera census district.

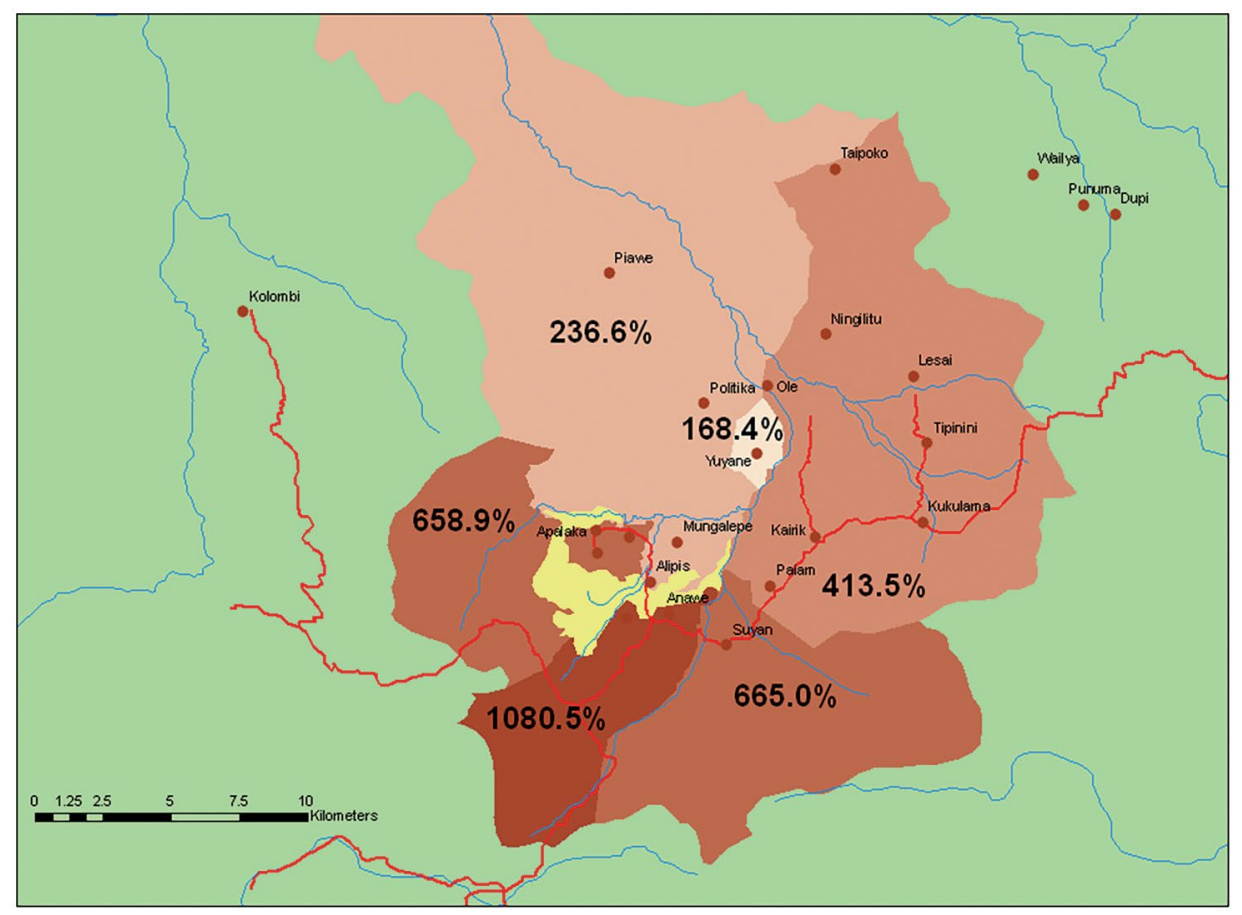

Figure 5.4 Population increase in Porgera census district, 1980-2000.

Note: The area in yellow is the Porgera mine.

Source: Image created by author using ArcGIS.

As seen in Figures 5.3 and 5.4, populations in high-elevation areas of Porgera have grown by approximately seven to ten times their 1980 populations. The area around Kairik where this study was done has experienced a greater than fourfold increase in population. As a result of these patterns, most of the 
impacts on Porgera's forests have been in high-elevation areas. While these forests can supply the needs of locals and immigrants in their primary states, as demonstrated in the Social Context and Land Tenure Rules section, the secondary high-elevation forests are extremely resource poor with no major hardwood species growing in these forests that can be used for firewood, fences or building materials.

While outsiders were initially welcomed, today land and trees along the Enga Highway are valuable and frequently contested commodities. Numerous intergroup fights and killings have occurred from the late 1990s over the land and resources along the road. Beginning in the mid-2000s, several groups started creating 'forest reserves' in mid-elevation primary forests that could only be used by an exclusive set of clan members who had received permission to cut individual trees in these reserves.

But do the creation of forest reserves, the onset of large-scale mining development and population explosions due to immigration mean that primary rainforest is disappearing in the Porgera Valley? Contrary to the argument by Shearman et al. $(2008,2009)$ that shifting cultivation is one of the two primary drivers of deforestation of primary rainforest in PNG, McAlpine and Freyne (2001) demonstrate that while PNG's rural population increased by 50 per cent between 1975 and 1996, the total amount of land that went into agricultural production to sustain this population increase expanded by only 11 per cent. As a consequence, rural agriculturists are deploying a range of intensification techniques to increase their yield (Bourke 2001) that are not dependent upon cutting primary rainforest. In fact, Allen et al. (2001: 533) determined the type of land cover that was cleared for planting gardens by rural agriculturalists 55.8 per cent was secondary forest, 12.9 per cent short woody regrowth, and 30.7 per cent either grass or mixed grass/woody regrowth. Only 0.5 per cent of the land area that was primary forest was cleared for gardens. Of course, Porgera has had vastly different rates of population growth than the nation as a whole. In 1971, a census was conducted which counted 4,020 people in Porgera. In terms of land use in 1972, approximately $448 \mathrm{~km}^{2}$ were primary rainforest and $25 \mathrm{~km}^{2}$ were gardens/cleared space. The 2000 census counted 22,809 people, about 5.7 times as many people than in the early 1970s. Land use for gardens more than doubled with $59 \mathrm{~km}^{2}$ as gardens/cleared space by 2002 . The amount of forest between 1972 and 2002 decreased by $36 \mathrm{~km}^{2}$ to $412 \mathrm{~km}^{2}$. Population increases in Porgera, therefore, appear to be closely related to loss of primary rainforest; however, intensification is also occurring. For example, in the early 1970s, each square kilometre of garden land supported about 160 people. By the early 2000s, each square kilometre of garden was supporting about 386 people. Of course, the ability to purchase outside food stuffs, mainly rice, certainly influences the latter equation. To summarise for Porgera, both deforestation and 
intensification are occurring to accommodate the massive population increases into the area. However, as argued in the preceding sections, these population and land use pressures have very localised ecological outcomes as a result.

\section{Conclusions}

Porgera's firewood crisis is a result of three interlocking forces resulting from local tenure and resource management practices, colonial history and forest succession dynamics. While Porgerans are active planters of economically important trees, such as $C$. oligodon, and manage forest succession through techniques relying upon shifting cultivation, recent demographic and sociocultural transformations challenge the ability of Porgerans to maintain sufficient forests in certain areas of the valley. Once welcomed outsiders are no longer able to plant trees on borrowed land due to land valuation increasing along the Enga Highway, and also because planting trees on a certain plot of land is a local cultural expression of the intent to claim ownership over that land. Population increases also hamper the effective management of forest succession by limiting the area of land available for shifting cultivation. The sociocultural dynamics of managing trees and forests may not have been hindered if not for the routing of the Enga Highway by outside, colonial decision makers away from mid-elevation hamlets into high-elevation forests. As Porgerans moved higher in altitude to be near the highway, they encountered vastly different conditions for crop production (Jacka 2009) and different forest succession dynamics from mid-elevation forests. While the two most economically important mid-elevation trees besides C. oligodon, pai (Castanopsis acuminatissima) and tato (Nothofagus sp.), grow well with some anthropogenic disturbances (van Valkenburg and Ketner 1994), secondary forests at high elevations are incredibly resource poor in terms of usable timber for firewood, fences and house building. Trying to balance this confluence of local resource management practices, exogenous historical decisions and ecological factors creates a social, economic, and ecological crisis for most Porgerans. Once-free resources are now commodities and social and ethnic tensions have flared into large-scale resource conflicts (Biersack 2006).

Analysis of the factors underlying the firewood crisis points to the need to approach human-environmental issues as complex, coupled human and natural systems (Gunderson and Holling 2002). The goal of this chapter was not to argue that high-elevation forests in Porgera were 'pristine' and are now under threat from increasing human populations and reduced carrying capacity. Rather, the goal was to examine how human societies and the rainforests in which they live are mutually constitutive (Bayliss-Smith et al. 2003) and how certain internal and external forces challenge the resilience of these human-environmental complexes (Holling 1973). The data I have presented show that human exploitation of 
mid-elevation forests, while disruptive, is resilient in that key resources in less-exploited forest sections resemble those of exploited sections. The same cannot be said for human exploitation of high-elevation forests in Porgera and probably elsewhere in PNG. This highlights an important policy distinction in that large-scale resource development plans in PNG need to be attentive to the coupled human-natural systems that they intend to impact. Future social and ecological impact assessments need to be more comprehensively synergistic by realising that the societies and environments of PNG comprise one tightly integrated system and not two disparate systems that occasionally interact with one another. Finally, debates about deforestation that focus solely on per annum rates of change or numbers of hectares cleared annually have the potential to overlook the local, culturally contingent and ecologically specific ways that forest resources are used across time in subsistence-based communities.

\section{References}

Allen, B., R.M. Bourke and L. Hanson, 2001. 'Dimensions of PNG Village Agriculture.' In R.M. Bourke, M.G. Allen and J.G. Salisbury (eds), Food Security of Papua New Guinea: Proceedings of the Papua New Guinea Food and Nutrition 2000 Conference. Canberra: Australian Centre for International Agricultural Research.

Ash, J., 1982. 'The Nothofagus Blume (Fagaceae) of New Guinea.' In J.L. Gressitt (ed.), Biogeography and Ecology of New Guinea. The Hague: Dr W. Junk Publishers.

Balée, W., 1989. 'The Culture of Amazonian Forests.' Advances in Economic Botany 7: 1-21.

Ballard, C., 1995. The Death of a Great Land: Ritual, History and Subsistence Revolution in the Southern Highlands of Papua New Guinea. Canberra: The Australian National University (PhD thesis).

Bayliss-Smith, T., E. Hviding and T.C. Whitmore, 2003. 'Rainforest Composition and Histories of Human Disturbance in Solomon Islands.' Ambio 32(5): $346-52$.

Biersack, A., 1995. 'Heterosexual Meanings: Society, Economy, and Gender among Ipilis.' In A. Biersack (ed.), Papuan Borderlands: Huli, Duna, and Ipili Perspectives on the Papua New Guinea Highlands. Ann Arbor: University of Michigan Press. 
Biersack, A., 1998. 'Horticulture and Hierarchy: The Youthful Beautification of the Body in the Paiela and Porgera Valleys.' In G. Herdt and S.C. Leavitt (eds), Adolescence in Pacific Island Societies. Pittsburgh: University of Pittsburgh Press.

Biersack, A., 2004. 'The Bachelors and Their Spirit Wife: Interpreting the Omatisia Ritual of Porgera and Paiela.' In P. Bonnemère (ed.), Women as Unseen Characters: Male Ritual in Papua New Guinea. Philadelphia: University of Pennsylvania Press.

Biersack, A., 2006. 'Red River, Green War: The Politics of Nature along the Porgera River.' In A. Biersack and J.B. Greenberg (eds), Reimagining Political Ecology. Durham (NC): Duke University Press.

Bourke, R.M., 2001. 'Intensification of Agricultural Systems in Papua New Guinea.' Asia Pacific Viewpoint 42(2/3): 219-35.

Bourke, R.M. and T. Harwood (eds), 2009. Food and Agriculture in Papua New Guinea. Canberra: ANU E Press.

Chapman, C.A. and L.J. Chapman, 2004. 'Unfavorable Successional Pathways and the Conservation Value of Logged Tropical Forest.' Biodiversity and Conservation 13(11): 2089-105.

Dambacher, J., D. Brewer, D. Dennis, M. MacIntyre and S. Foale, 2007. 'Qualitative Modelling of Gold Mine Impacts on Lihir Island's Socioeconomic System and Reef-Edge Fish Community.' Environmental Science \& Technology 41(2): 555-62.

Fairhead, J. and M. Leach, 1996. 'False Forest History, Complicit Social Analysis: Rethinking Some West African Environmental Narratives.' World Development 23(6): 1023-35.

FAO (Food and Agriculture Organization of the United Nations), 2005. Global Forest Resources Assessment 2005. Rome: FAO.

FAO (Food and Agriculture Organization of the United Nations), 2010. Global Forest Resources Assessment 2010. Rome: FAO.

Filer, C., 2010. 'The Impacts of Rural Industry on the Native Forests of Papua New Guinea.' Pacific Economic Bulletin 25(3): 135-53.

Filer, C. (ed.), 1999. Dilemmas of Development: The Social and Economic Impact of the Porgera Gold Mine, 1989-1994. Canberra: Asia Pacific Press.

Filer, C., R.J. Keenan, B.J. Allen and J.R. McAlpine, 2009. 'Deforestation and Forest Degradation in Papua New Guinea.' Annals of Forest Science 66(813). 
Gordon, R.J. and M.J. Meggitt, 1985. Law and Order in the New Guinea Highlands: Encounters with Enga. Hanover (NH): University Press of New England.

Gunderson, L. and C.S. Holling (eds), 2002. Panarchy: Understanding Transformations in Human and Natural Systems. Washington: Island Press.

Hide, R., M. Kimin, A. Kora, G. Kua and K. Kua, 1979. A Checklist of Some Plants in the Territory of the Sinasina Nimai (Simbu Province, Papua New Guinea), with Notes on Their Uses. Auckland: University of Auckland, Department of Anthropology.

Holling, C.S., 1973. 'Resilience and Stability of Ecological Systems.' Annual Review of Ecology and Systematics 4: 1-23.

Hyndman, D., 1979. Wopkaimin Subsistence: Cultural Ecology in the New Guinea Highland Fringe. University of Queensland (PhD thesis).

Ingemann, F., n.d. 'Ipili Dictionary.' Unpublished manuscript.

Jacka, J.K., 2009. 'Global Averages, Local Extremes: The Subtleties and Complexities of Climate Change in Papua New Guinea.' In S. Crate and M. Nutall (eds), Anthropology and Climate Change: From Encounters to Actions. Walnut Grove (CA): Left Coast Press.

Jacka, J.K., 2010. 'The Spirits of Conservation: Ecology, Christianity, and Resource Management in Highlands Papua New Guinea.' Journal for the Study of Religion, Nature and Culture 4(1): 24-47.

Jackson, R. and G. Banks, 2002. In Search of the Serpent's Skin: The Story of the Porgera Gold Project. Port Moresby: Placer Niugini Ltd.

Johns, R.J., 1982. 'Plant Zonation.' In J.L. Gressitt (ed.), Biogeography and Ecology of New Guinea. The Hague: Dr W. Junk Publishers.

Krebs, C., 1989. Ecological Methodology. New York: Harper Collins Publishers.

Majnep, I.S. and R. Bulmer, 1977. Birds of My Kalam Country. Oxford: Oxford University Press.

McAlpine, J. and D.F. Freyne, 2001. 'Land Use Change and Intensification in Papua New Guinea 1975-1996.' Asia Pacific Viewpoint 42(2/3): 209-218.

Meggitt, M.J., 1977. Blood Is Their Argument: Warfare among the Mae Enga Tribesmen of the New Guinea Highlands. Palo Alto (CA): Mayfield Publishing Company. 
Naughton-Treves, L., D.M. Kammen and C. Chapman, 2007. 'Burning Biodiversity: Woody Biomass Use by Commercial and Subsistence Groups in Western Uganda's Forests.' Biological Conservation 134: 232-41.

Paijmans, K., 1976. New Guinea Vegetation. Amsterdam: Elsevier Scientific Publishing Company.

Parikka, M., 2004. 'Global Biomass Fuel Resources.' Biomass and Bioenergy 27(6): 613-20.

Parker, E., 1993. 'Fact and Fiction in Amazonia: The Case of the Apêtê.' American Anthropologist 95(3): 715-23.

Posey, D., 1985. 'Indigenous Management of Tropical Forest Ecosystems: The Case of the Kayapù Indians of the Brazilian Amazon.' Agroforestry Systems 3(2): 139-58.

Primack, R. and R. Corlett, 2005. Tropical Rain Forests: An Ecological and Biogeographical Comparison. Oxford: Blackwell Publishers.

Robbins, R.G., 1961. 'The Montane Vegetation of New Guinea.' Tuatara 8: $121-34$.

Robbins, R.G. and R. Pullen, 1965. 'Vegetations of the Wabag-Tari Area.' In General Report on Lands of the Wabag-Tari Area, Territory of Papua and New Guinea, 1960-61. Melbourne: Commonwealth Scientific and Industrial Research Organisation (Land Research Series 15).

Scoones, I., 1999. 'New Ecology and the Social Sciences: What Prospects for a Fruitful Engagement?' Annual Review of Anthropology 28: 479-507.

Shearman, P.L., J. Ash, B. Mackey, J.E. Bryan and B. Lokes, 2009. 'Forest Conversion and Degradation in Papua New Guinea 1972-2002.' Biotropica 41(3): 379-90.

Shearman, P., J. Bryan, J. Ash, P. Hunnam, B. Mackey and B. Lokes, 2008. The State of the Forests of Papua New Guinea: Mapping the Extent and Condition of Forest Cover and Measuring the Drivers of Forest Change in the Period 1972-2002. Port Moresby: University of Papua New Guinea.

Shearman, P., J. Bryan, J. Ash, B. Mackey and B. Lokes, 2010. 'Deforestation and Degradation in Papua New Guinea: A Response to Filer and Colleagues, 2009.' Annals of Forest Science 67(300): 300.

Sillitoe, P., 1996. A Place against Time: Land and Environment in the Papua New Guinea Highlands. Amsterdam: Harwood Academic Publishers. 
Struhsaker, T.T., 1997. Ecology of an African Rain Forest: Logging in Kibale and the Conflict between Conservation and Exploitation. Gainesville: University Press of Florida.

van Valkenburg, J. and P. Ketner, 1994. 'Vegetation Changes Following Human Disturbance of Mid-Montane Forest in the Wau Area, Papua New Guinea.' Journal of Tropical Ecology 10(1): 41-54.

Vayda, A.P. and B. Walters, 1999. 'Against Political Ecology.' Human Ecology 27(1): 167-79.

Waddell, E., 1975. 'How the Enga Cope with Frost: Responses to Climatic Perturbations in the Central Highlands of New Guinea.' Human Ecology 3(4): 249-73.

Willis, K.J., L. Gillson and T.M. Brncic, 2004. 'How “Virgin" is Virgin Rainforest?' Science 304: 402-3.

Wohlt, P.B., 1995. 'System Integrity and Fringe Adaptations.' In A. Biersack (ed.), Papuan Borderlands: Huli, Duna, and Ipili Perspectives on the Papua New Guinea Highlands. Ann Arbor: University of Michigan Press. 
This text is taken from Tropical Forests of Oceania: Anthropological Perspectives, edited by Joshua A. Bell, Paige West and Colin Filer, published 2015 by ANU Press, The Australian National University, Canberra, Australia. 